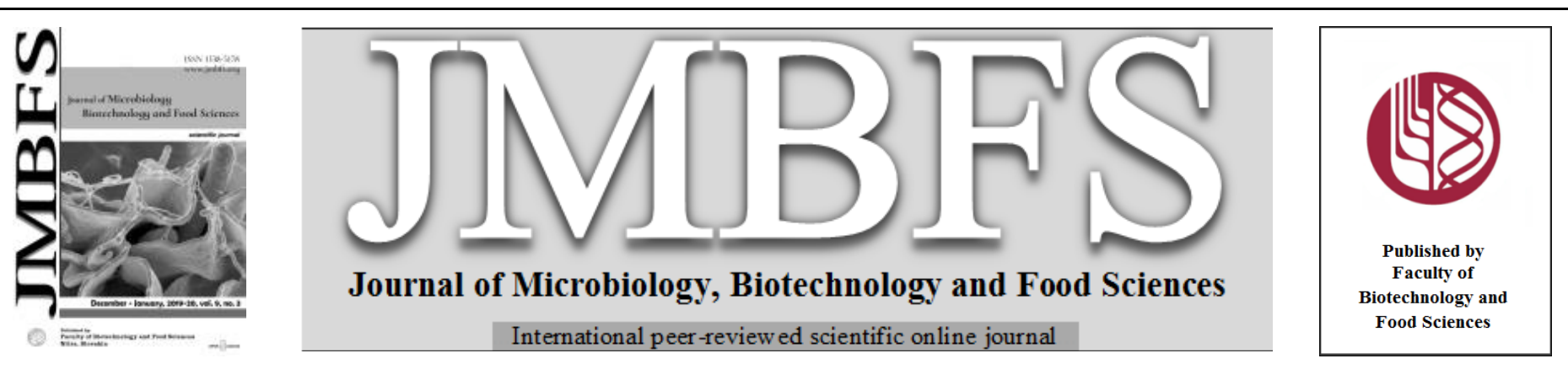

\title{
EXPLORATION OF ANTIBACTERIAL AND ANTIPROLIFERATIVE SECONDARY METABOLITES FROM MARINE BACILLUS
}

\author{
Chandini S Syed, Mantri Sairam, Amrutha V Audipudi*
}

Address(es):

${ }^{a}$ Department of Microbiology, Acharya Nagarjuna University, Andhra Pradesh - 522510, India

*Corresponding author: audipudiamrita@gmail.com

doi: 10.15414/jmbfs.2019/20.9.3.628-633

\section{ARTICLE INFO}

Received 5. 12. 2018

Revised 27. 6. 2019

Accepted 27. 6. 2019

Published 1. 12. 2019

Regular article

open $\partial_{\text {access }}$

\section{ABSTRACT}

Antiproliferative secondary metabolites producing bacterial strain AVSC4 isolated from marine sediments was identified as Bacillus flexus based on 16S rRNA gene sequence analysis. Under the strategy of liquid- liquid extraction, the crude extract was obtained showed significant antibacterial activity against different clinical pathogens. $0.5 \%$ methionine and $0.4 \% \mathrm{NaCl}$ act as inducers for maximizing the growth and antibacterial activity of strain at $\mathrm{pH} 7$ and $40^{\circ} \mathrm{C}$. Heptadecanoic acid and methyl hexadecanoic acid were identified as major and dominant secondary metabolites by GC-MS analysis and also showed significant antiproliferative activity against HT-29 (Human colorectal adenocarcinoma) and A-549 (Lung Cancer) with $\mathrm{IC}_{50}$ value $93.4 \mu \mathrm{g} / \mathrm{ml} \mathrm{and} 50.04 \mu \mathrm{g} / \mathrm{ml}$.

Keywords: Antibacterial, antiproliferative, A-549 cell line, Bacillus flexus AVSC4, GC-MS analysis, HT-29 cell line

\section{INTRODUCTION}

The antibacterial activities of long-chain unsaturated fatty acids have been well known for many years. Fatty acids function as the key ingredients of antimicrobial food additives which inhibit the growth of unwanted microorganisms (Freese et al 1973). Besides normal fatty acids, fatty acid derivatives showing potent antimicrobial activities exist in nature and also mediate chemical defense against microorganisms (Pfefferle et al 1996, Lopez and Gerwick 1988, Dellar et al 1996).

Marine bacteria have developed a complex biochemical and physiological systems which can adapt to extreme and unfavorable condition. They produce unique secondary metabolites which have shown significant applications in biotechnology and pharmaceutical industries (Wenzel and Muller, 2005). Nove compounds so far isolated from marine organisms have been identified as antibiotics, anticancer enzymes and antimicrobial compounds examined for their pharmacological activity were not completely explored (Jensen and Fenical, 1994; Pomponi, 1999). However it was only in the mid of $20^{\text {th }}$ century, enormous interest has been shown by the scientists to explore oceans for biologically active compounds (Proksh et al., 2002). Recent investigations showed that secondary metabolites produced by marine bacteria were potential drugs used to treat cancer, inflammations, (Burgess et al., 1991; Bhatnagar and Kim, 2010) bacterial, fungal, protozoan and viral infections (Villa and Gerwick, 2010; Mayer et al., 2011). It is now well known that antibiotic resistance has become a global challenge, hence search of bioactive metabolites from marine environment is gaining more attention in recent years (Ramachandran et al 2014).

Most of the bioactive compounds from the marine Bacillus are industrially worthy and have a history of safe usage. Bacilli are especially known for the production of a vast array of structurally distinct antimicrobial compounds, which include surfactin, iturin, fengycins and bacteriocins (Stein, 2005). Ravikumar et al, (2010) reported that $B$. thuringiensis and B. pumilus of mangrove origin are potential antibacterial agents against human pathogenic bacteria. B. subtilis (Jansen and Hirschmann, 1944), $B$. coagulans (Hyronimus et al., 1998) and $B$ megaterium (Von Tersch and Carlton, 1983) are not only capable of producing bacteriocins but also acts as biocontrol agents (Wulff et al., 2002).

Optimization of the nutritional and culture conditions of the bacteria can enrich the fermentation profile including $\mathrm{pH}$ of media, incubation and temperature etc. Therefore optimal variables of physicochemical parameters are utmost importan in increasing the production of bioactive compounds (Nagar et al., 2012) Bacillus species are well known to produce unsaturated fatty acids, however a petite portion of work has done on their biological activities. 12- methyl tridecanoic (iso-C14), 14-methyl pentadecanoic (iso-C16), and 14-methyl hexadecanoic (anteiso-C,7) were some of the fatty acids reported from B. subtilis (Kaneda, 1963). Bioactive compounds produced from the fermentation broth of marine B. mojavensis B0621A, displayed antifungal activity against a broad spectra of phytopathogens as well as cytotoxic activities against the human leukemia (HL-60) cell line with IC50 values of 100,100 , and $1.6 \mu \mathrm{M}$, respectively (Ma, et al., 2010).

Exploration of potential antibiotics from marine microorganisms with low cost and less adverse effects has become essential biomedical research. Search for antibiotic producing marine organisms explored marine habitats, characterization and optimization of culture conditions for the exploration of novel secondary metabolites potential to antibiotic and anticancer is a continuous exercise. With this background the present research aimed to explore antibiotic and antiproliferative secondary metabolites of Bacillus flexus isolated from the Bay of Bengal from India and its identification, characterization and optimization of culture conditions

\section{MATERIALS AND METHODS}

A total of 15 soil samples were collected from sediment soils of Suryalanka, Andhra Pradesh, India. A preliminary screening medium composed of Beef extract, Peptone, $\mathrm{NaCl}$ and Agar were obtained from HiMedia Laboratories (Mumbai) Ltd. All the pathogenic strains were obtained from Microbial Type Culture Collection centre (MTCC). Human colorectal adenocarcinoma (HT-29) and Lung Cancer (A-549) cell lines obtained from the National Center for cellular Sciences (NCCS), Pune, India.

Screening, Isolation and identification of bioactive compounds producing strains

Bacillus flexus AVSC4 strain, producing potential antibacterial compounds (Chandini et al., 2017) was isolated and the Pure culture of the strain was maintained and periodically subcultured on nutrient Agar Medium in corresponding authors laboratory. Molecular identification of marine isolate AVSC4 was carried out by $16 \mathrm{~S}$ rRNA partial gene sequencing. PCR amplification of $16 \mathrm{~S}$ rRNA gene was done by using universal primers $27 \mathrm{~F}($ AGAGTTTGATCCTGGCTCAG) and 1492 R (GGTTACCTTGTTACGACTT) with the conditions ( 1 min predenaturation at $94{ }^{\circ} \mathrm{C}, 30$ cycles of denaturation for 30 seconds at $94{ }^{\circ} \mathrm{C}, 30$ seconds annealing at $55^{\circ} \mathrm{C}, 1$ min extension at $72{ }^{\circ} \mathrm{C}$ and 10 min termination at $72{ }^{\circ} \mathrm{C}$ ) as described (Chalasani et al., 2015). The PCR product was sequenced at Macrogen South Korea and analysed with the GenBank database, National Center for Biotechnology Information (NCBI) server (http://www.ncbi.nlm.nih.gov) using Basic Local Alignment Search Tool 
(blastn) tool. Phylogenetic tree was constructed with Neighbour joining method. Phylogenetic tree was constructed by comparing the sequence with GenBank database using Mega 5.0 software (Tamura et al., 2011).

\section{Antibacterial activity}

Escherichia coli (MTCC 1696), Klebsiella pneumonia (MTCC4030), Proteus vulgaris (MTCC7299), Salmonella typhi (MTCC 8587), Serretia marcescens (MTCC2645) and Staphylococcus aureus (MTCC 3160) were used as target pathogens with Streptomycin and DMSO as positive and negative control. The test organisms were grown in nutrient broth. 24 hours old test organisms were inoculated by spreading pathogenic inoculum on NAM plates. 6-mm diameter wells were punched in the medium with a sterile borer. $60 \mu \mathrm{l}$ of the crude extract of AVSC4 was introduced into each well and plates were incubated at $37^{\circ} \mathrm{C}$ for 24-48 hours. After incubation, the diameter of each zone in millimeters was measured and results were recorded (Balouiri et al., 2016). The experiment was performed in triplicates.

\section{Growth characteristics evaluation and anti bacterial activity optimization}

The isolated strain was transferred into flasks containing $50 \mathrm{ml}$ of nutrient broth and incubated at $37{ }^{\circ} \mathrm{C}$ on a rotary shaker at $200 \mathrm{rpm}$. Optimization was carried out at different incubation periods $(24,48,72,96$ and 120hrs), Temperature (25 $\left.{ }^{\circ} \mathrm{C}, 30{ }^{\circ} \mathrm{C}, 35{ }^{\circ} \mathrm{C}, 40{ }^{\circ} \mathrm{C}, 45{ }^{\circ} \mathrm{C}\right), \mathrm{pH}(1,2,3,4,5,6,7,8$ and 9$), \mathrm{NaC}$ concentration $(0.2 \%, 0.3 \%, 0.4 \%, 0.5 \%, 0.6 \%, 0.7 \%, 0.8 \%, 0.9 \%, 1.0 \%), 0.5 \%$ Carbon sources (Glucose, Sucrose, Dextrose, Maltose, Lactose, Mannose, Fructose, Galactose, Starch, Glycerol and D-Arabinose) $0.5 \%$ nitrogen source (Sodium acetate, Peptone, Beef extract, yeast extract, Sodium nitrate Ammonium sulphate, Urea) and $0.5 \%$ amino acids (Cysteine, Leucine, Methionine, Tryptophan, Glycine, Alanine and Proline) separately . The growth of the isolate was determined by measuring OD at $540 \mathrm{~nm}$.

\section{Extraction of crude}

AVSC4 was grown in optimized fermentation medium (NAM supplemented with $0.5 \%$ Peptone, $0.5 \%$ Beef extract, $0.4 \%$ Sodium chloride and $0.5 \%$ Glucose) at $\mathrm{pH} 7.0$ and $30{ }^{\circ} \mathrm{C}$ for $96 \mathrm{~h}$ on a rotary shaker at $200 \mathrm{rpm}$ for four days. After 96 hours of incubation, the culture was harvested and centrifuged at 10,000 rpm for $20 \mathrm{~min}$ at $4{ }^{\circ} \mathrm{C}$ and supernatant was collected. An equal volume of ethyl acetate was added to the collected supernatant and vigorously shaken for 30-40 min. The organic layer was fractionated with a separating funnel. The extraction was repeated twice with equal volume of ethyl acetate and collected organic layer was evaporated to dryness in a rota evaporator under reduced pressure. The extracted pellet was dissolved in DMSO and used for further investigation (Zheng et al. 2014).

\section{Antiproliferation activity}

Crude extract of AVSC4 was assessed for in vitro cytotoxicity by MTT assay. Doxorubicin was used as a standard. 96 well plates were loaded with $100 \mu$ media at a density of 10,000 cells per well and grown for $24 \mathrm{~h}$. The cells were then exposed to different concentrations (10 to $200 \mu \mathrm{g} / \mathrm{ml}$ ) of the test compounds for $48 \mathrm{~h}$. $10 \mu \mathrm{l}$ of MTT solution ( $5 \mathrm{mg} / \mathrm{ml}$ in PBS) was added to each well $(90 \mu$ of the media) and incubated for four hours at $37{ }^{\circ} \mathrm{C}$. After incubation, $200 \mu 1$ of DMSO was added to each well and the absorbance was measured at $570 \mathrm{~nm}$. The mean $\%$ of cell viability in relation to untreated cells was estimated from data of triplicates (Venkanna et al., 2014). The percentage growth inhibition was calculated using the formula:

$\%$ inhibition $=100 \underline{(\text { control-treatment })}$

control

\section{Gas Chromatography-Mass Spectroscopy (GC-MS) Analysis}

The ethyl acetate crude extract of AVSC4 was analyzed on mass spectrum of GC-MS (GCMSQP2010, SHIMADZU) by applying the database of National Institute standard and Technology which includes more than 62000 patterns (Basa'ar et al., 2017). The chromatogram obtained exhibited the availability of fifteen active principles. The name, retention time, molecular formula and percentage area of expected compounds were tabulated in (Table 2).

\section{Statistical analysis}

Experiments were conducted in triplicates and results were statistically analyzed by single ANOVA with Turkeys HSD pair wise and Duncan's Multiple comparisons using XL STAT 2018 Version-1.49342 software.

\section{RESULTS}

\section{Isolation and identification of bioactive compound producing bacteria}

In this study bacterial strains isolated of 15 soil samples collected from different regions of Bay of Bengal at a distance of one meter, 23 bacterial strains showed antibacterial activity of which AVSC4 strain was observed as one of the potential strain. 16S rRNA gene sequence of AVSC4 showed similarity with Bacillus flexus C116 and Bacillus sp. JDMASP51 strain and deposited in GEN BANK, NCBI as Bacillus flexus AVSC4 with GenBank accession no. MG878436.

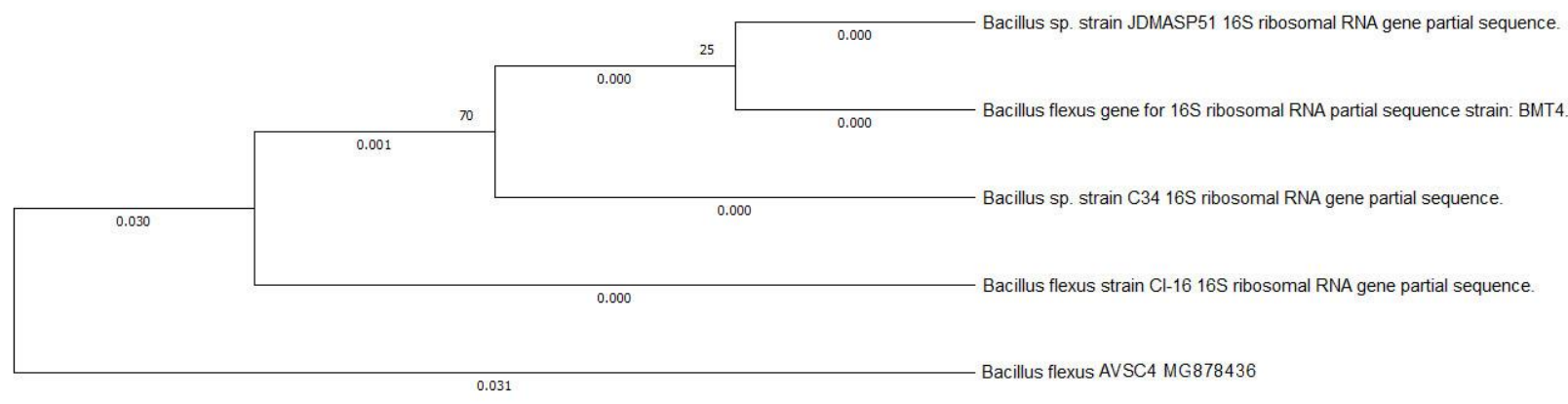

Figure 1 Phylogenetic analysis of 16S rRNA partial gene sequence of Bacillus flexus AVSC4

\section{Optimization studies for growth and antibacterial compound production}

Impact of optimization on growth and antibacterial activity of AVSC4 was analyzed at different physical and chemical factors such as incubation period, temperature, $\mathrm{pH}$, salinity, carbon sources, nitrogen sources and amino acids. Antibacterial activity of AVSC4 and its correlation with growth was studied against E.coli. Highest antibacterial activity was observed at 96 hours and 120 hours of incubation at $35{ }^{\circ} \mathrm{C}$ and $40{ }^{\circ} \mathrm{C}$, pH 7 and $\mathrm{pH} 8,0.4 \% \mathrm{NaCl}$. Maximum antibacterial activity at $40{ }^{\circ} \mathrm{C}$ indicates thermo stability of AVSC4 isolate and adaptability to culture conditions by expressing maximum antibiotic activity at $\mathrm{pH} 7$ and $\mathrm{pH} 8$ followed by $0.4 \%$ and $0.5 \% \mathrm{NaCl}$. In order to bring culture conditions to recommended laboratory parameters, $40^{\circ} \mathrm{C}, \mathrm{pH} 7$ and $0.4 \% \mathrm{NaCl}$ were opted and further investigation of impact of chemical factors (carbon, nitrogen sources and amino acids ) have been analyzed in the ethyl acetate extract recovered from the isolate grown in optimized conditions $\left(40{ }^{\circ} \mathrm{C}, \mathrm{pH} 7,0.4 \%\right.$ $\mathrm{NaCl}$ ). $96 \mathrm{hrs}$ and $120 \mathrm{hrs}$ incubation periods have shown maximum antibacterial activity in presence of Glucose, Sucrose and Dextrose (Carbon Sources), Beef extract (Nitrogen source) and Methionine (Amino acid). Based on the observations, the formulated culture media composition is glucose $0.5 \%$, beef extract $0.5 \%$, methionine $0.5 \%, \mathrm{NaCl} 0.4 \%$ at $40{ }^{\circ} \mathrm{C}, \mathrm{pH} 7.0$ and 96 hours of incubation. 

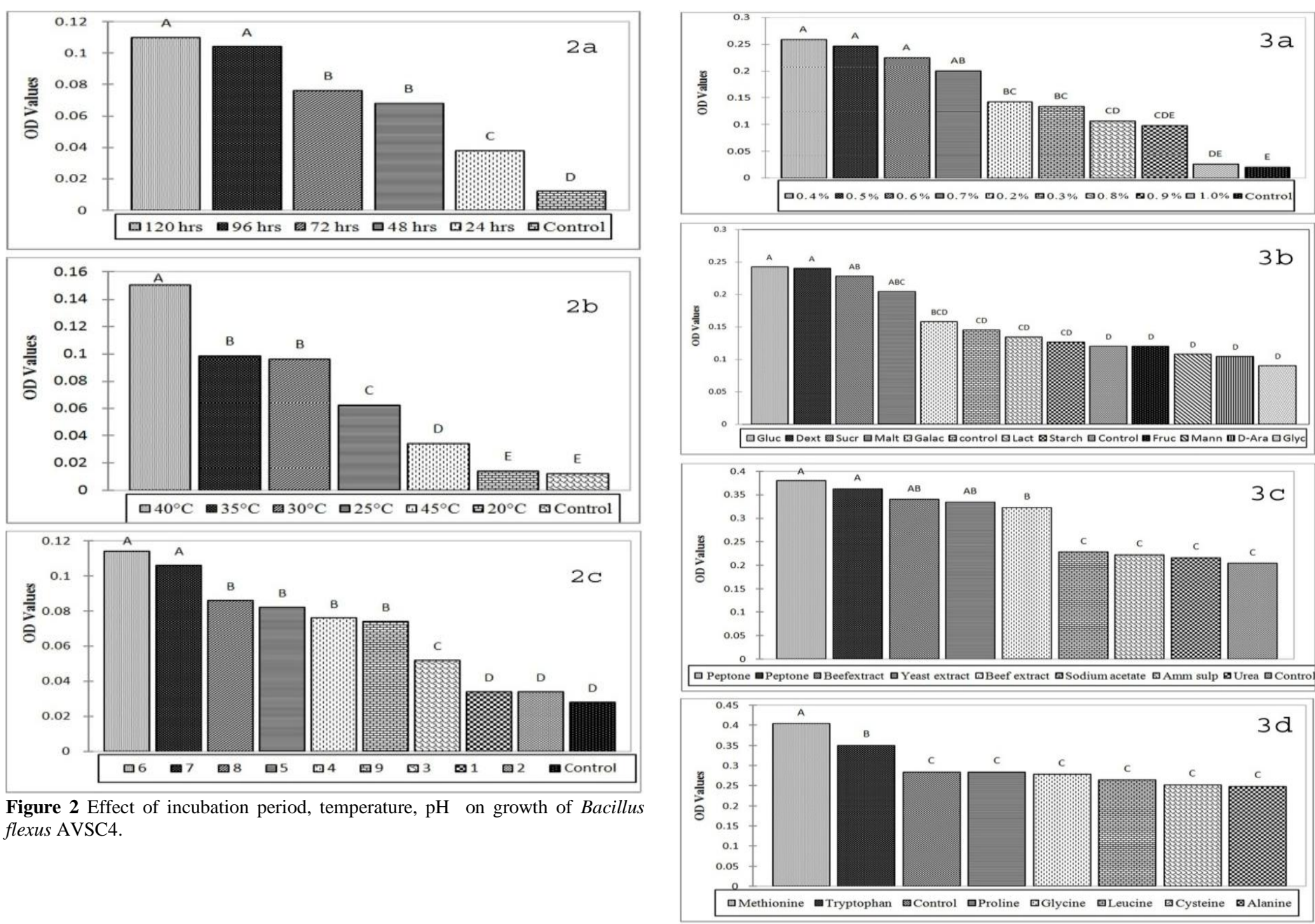

Figure 3 Effect of salinity concentration, carbon sources, nitrogen sources and amino acids on growth of Bacillus flexus AVSC4.

Table 1 Antibacterial activity for optimized broth against human pathogen Escherichia coli

\begin{tabular}{|c|c|c|c|c|c|}
\hline Temperature & $24 \mathrm{hrs}$ & $48 \mathrm{hrs}$ & $72 \mathrm{hrs}$ & $96 \mathrm{hrs}$ & $120 \mathrm{hrs}$ \\
\hline $25^{\circ} \mathrm{C}$ & - & - & . & - & + \\
\hline $30^{\circ} \mathrm{C}$ & - & - & 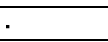 & ++ & ++ \\
\hline $35^{\circ} \mathrm{C}$ & - & - & + & ++ & ++ \\
\hline $40^{\circ} \mathrm{C}$ & - & - & + & +++ & +++ \\
\hline $45^{\circ} \mathrm{C}$ & - & - & . & - & + \\
\hline \multicolumn{6}{|l|}{ pH } \\
\hline 1 & - & - & - & - & - \\
\hline 2 & - & - & - & - & - \\
\hline 3 & - & - & - & - & - \\
\hline 4 & - & - & - & - & - \\
\hline 5 & - & - & - & - & - \\
\hline 6 & - & - & - & + & + \\
\hline 7 & - & - & - & +++ & +++ \\
\hline 8 & - & - & - & +++ & +++ \\
\hline 9 & - & - & - & - & - \\
\hline \multicolumn{6}{|c|}{ Salinity concentration } \\
\hline $0.2 \%$ & - & - & - & - & - \\
\hline $0.3 \%$ & - & - & - & - & - \\
\hline $0.4 \%$ & - & - & + & +++ & ++++ \\
\hline $0.5 \%$ & - & - & ++ & +++ & +++ \\
\hline $0.6 \%$ & - & - & + & ++ & ++ \\
\hline $0.7 \%$ & - & - & - & + & + \\
\hline $0.8 \%$ & - & - & - & - & - \\
\hline $0.9 \%$ & - & - & - & - & - \\
\hline $1.0 \%$ & - & - & - & - & - \\
\hline \multicolumn{6}{|l|}{ Carbon sources } \\
\hline Glucose & - & - & - & +++ & +++ \\
\hline Sucrose & - & - & - & +++ & ++ \\
\hline Dextrose & - & - & - & +++ & +++ \\
\hline Maltose & - & - & - & ++ & ++ \\
\hline Lactose & - & - & - & ++ & + \\
\hline Mannose & - & - & - & + & + \\
\hline Fructose & - & - & - & + & ++ \\
\hline
\end{tabular}




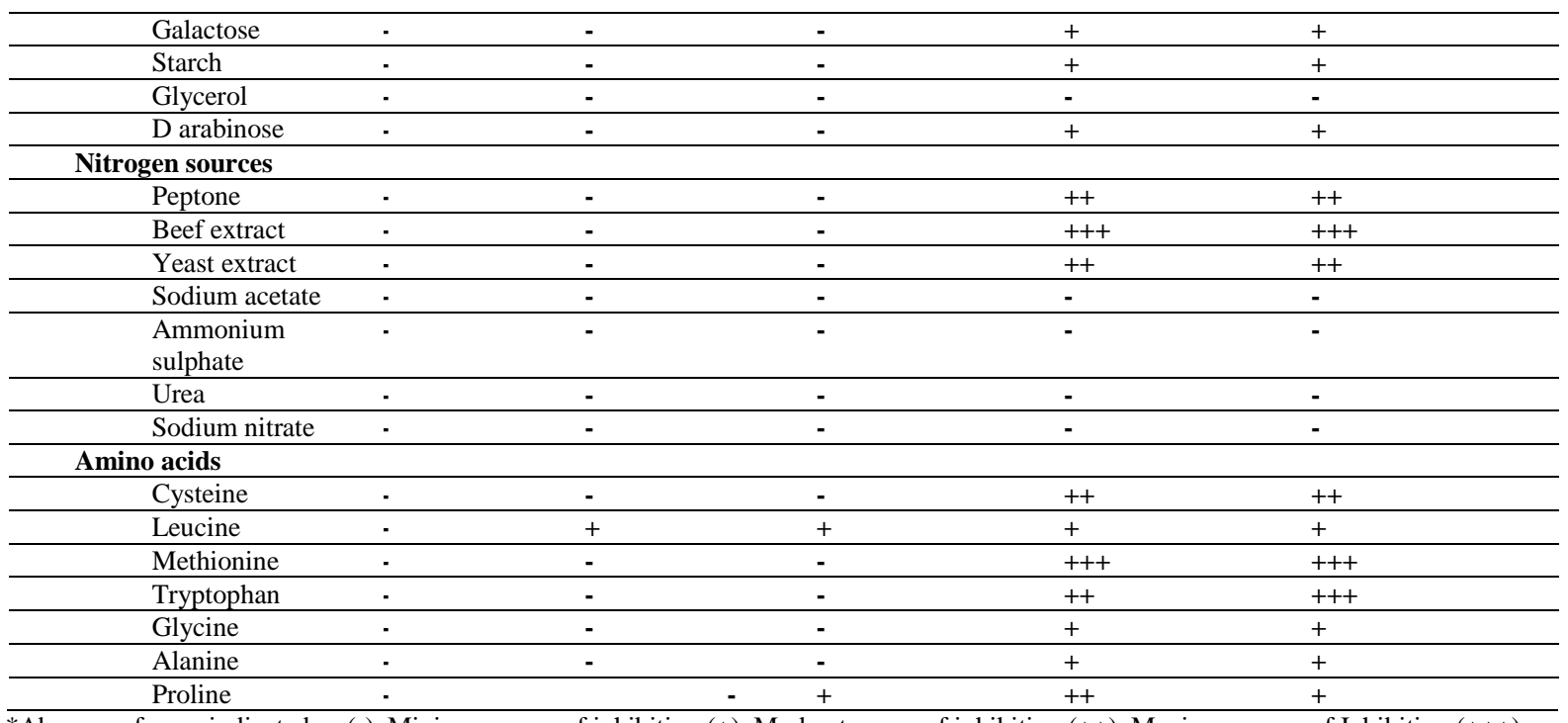

*Absence of zone indicated as (-), Minimum zone of inhibition (+), Moderate zone of inhibition (++), Maximum zone of Inhibition (+++).

\section{Antibacterial activity of isolate AVSC4 against different clinical pathogens at 96 hours}

Antibacterial activity was analysed using crude Ethyl Acetate - extract of AVSC4 grown in formulated culture broth against five clinical pathogens (Fig 4). The Crude extract of AVSC4 has shown maximum inhibitory activity against K.pneumonia $(16.8 \pm 0.2 \mathrm{~mm})$, E.coli $(15.0 \pm 0.1 \mathrm{~mm})$, S.typhi $(12.8 \pm 0.2 \mathrm{~mm})$, P.vulgaris (12.6 \pm 0.5$)$, S.aureus $(10.5 \pm 0.1 \mathrm{~mm})$ and S.marcescens $(09.0 \pm 0.2 \mathrm{~mm})$.

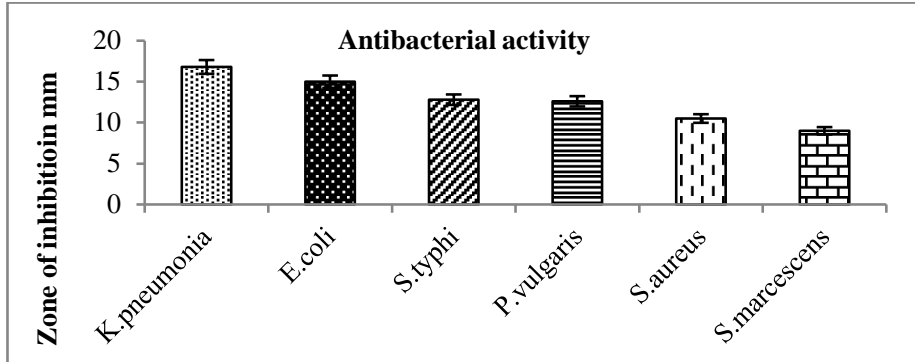

\section{GC-MS analysis}

The plethora of compounds present in AVSC4 was identified by GC-MS analysis. GC-MS chromatogram of the ethyl acetate extract of AVSC4 recorded 15 peaks indicating the presence of the many antimicrobial bioactive metabolites (Table 2). Out of 15 peaks separated in GC- MS chromatogram, the eighth peak is the highest peak (1060268) and the maximum percentage area $(29.04 \%)$ followed by the seventh peak ( 8.53 area). Based on NIST normal database seventh and eighth peaks were identified as methyl haptadecanoic acid and methyl hexadecanoic acid. Earlier reports on GC- MS of other organisms revealed that this compound could be potential antibacterial and anticancer secondary metabolites.

Figure 4 Antibacterial activity of Bacillus flexus AVSC4 crude extract against clinical pathogens.

Table 2 Secondary metabolites identified in ethyl acetate extract of B. flexus AVSC4 by GC-MS analysis.

\begin{tabular}{lccccccccll}
\hline Peak & R.Time & I. Time & F.Time & Area & Area\% & Height & $\begin{array}{c}\text { Height } \\
\%\end{array}$ & A/H & $\begin{array}{c}\text { Base } \\
\text { M/Z }\end{array}$ & Name \\
\hline 1. & 1.255 & 1.233 & 1.283 & 266113 & 0.24 & 240929 & 0.49 & 1.10 & 44.95 & Isopropyl Alcohol \\
\hline 2. & 7.124 & 7.075 & 7.183 & 5203545 & 4.62 & 3179971 & 6.52 & 1.64 & 73.90 & Octanoic acid, methyl ester \\
\hline 3. & 10.116 & 10.067 & 10.192 & 6204093 & 5.51 & 3602768 & 7.39 & 1.72 & 73.90 & Decanoic acid, methyl ester \\
\hline 4. & 13.163 & 13.100 & 13.217 & 6835299 & 6.07 & 3168019 & 6.50 & 2.16 & 73.90 & Dodecanoic acid, methyl ester \\
\hline 5. & 16.264 & 16.200 & 16.317 & 7131082 & 6.34 & 3363665 & 6.90 & 2.12 & 73.90 & Methyl tetradecanoate \\
\hline 6. & 18.791 & 18.742 & 18.850 & 4334974 & 3.85 & 2055790 & 4.22 & 2.11 & 54.95 & 9-Hexadecanoic acid, methyl ester \\
\hline 7. & 19.075 & 19.008 & 19.133 & 9602810 & 8.53 & 4378122 & 8.98 & 2.19 & 73.90 & Methyl hexadecanoate \\
\hline 8. & 20.406 & 20.300 & 20.467 & 32683937 & 29.04 & 11060268 & 22.69 & 2.96 & 73.90 & Heptadecanoicacid,methyl ester \\
\hline 9. & 21.225 & 21.167 & 21.258 & 4139376 & 3.68 & 1931201 & 3.96 & 2.14 & 66.95 & $9,12-0$ ctadecadienoic acid methyl ester \\
\hline 10. & 21.309 & 21.258 & 21.375 & 8313627 & 7.39 & 3353778 & 6.88 & 2.48 & 55.00 & $\begin{array}{l}8,11,14-\text { Docosatrienoic acid methyl } \\
\text { ester }\end{array}$ \\
\hline 11. & 21.604 & 21.542 & 21.658 & 6534579 & 5.81 & 2967387 & 6.09 & 2.20 & 73.90 & Octadecanoic acid, methvl ester \\
\hline 12. & 23.904 & 23.842 & 23.958 & 6256714 & 5.56 & 2831739 & 5.81 & 2.21 & 73.90 & Eicosanoicacid, methyl ester \\
\hline 13. & 25.769 & 25.708 & 25.817 & 3832079 & 3.40 & 1721294 & 3.53 & 2.23 & 54.95 & $13-$ Docosenoic acid, methyl ester \\
\hline 14. & 26.021 & 25.958 & 26.075 & 5971181 & 5.30 & 2634750 & 5.40 & 2.27 & 73.90 & Methyl docosanoate \\
\hline 15. & 27.979 & 27.917 & 28.042 & 5255761 & 4.67 & 2264677 & 4.65 & 2.32 & 73.90 & Tetracosanoic acid,methyl ester \\
\hline
\end{tabular}

\section{Antiproliferation activity}

The ethyl acetate extract of Bacillus flexus AVSC -4 showed IC 50 value of 50.04 $\mu \mathrm{g} / \mathrm{ml}$ against A594 cell line and 93.4 against HT-29 cell lines. Highest percentage inhibition in cell proliferation of A-549 cancer cells was observed compared with HT-29 (Table 3). The crude extract is effective against HT-29 cell lines. Table 3 shows the increase in viability percentage in a dose dependent manner 
Table $3 \mathrm{IC}_{50}$ Values of AVSC4 extract and Doxorubicin against HT-29 and A-549 cell lines

\begin{tabular}{|c|c|c|c|c|c|c|c|c|c|}
\hline $\begin{array}{l}\text { Conc. } \\
(\mu \mathrm{g} / \mathrm{ml})\end{array}$ & $\begin{array}{l}\text { HT-29 Cell Line at } \\
570 \mathrm{~nm}\end{array}$ & Average-Blank & $\%$ Viability & $\mathrm{IC}_{50}(\mu \mathrm{g} / \mathrm{ml})$ & $\begin{array}{l}\text { A-549 Cell Line } \\
\text { at } 570 \mathrm{~nm}\end{array}$ & $\begin{array}{c}\text { Average- } \\
\text { Blank }\end{array}$ & $\%$ & Viability & $\mathrm{IC}_{50}(\mu \mathrm{g} / \mathrm{ml})$ \\
\hline 100 & $0.93 \pm 0.002$ & 0.928 & 48.996 & \multirow{8}{*}{93.4} & $0.844 \pm 0.002$ & 0.844 & & 41.969 & \multirow{8}{*}{50.041} \\
\hline 75 & $1.005 \pm 0.002$ & 1.003 & 52.956 & & $0.92 \pm 0.002$ & 0.92 & & 45.748 & \\
\hline 50 & $1.074 \pm 0.002$ & 1.072 & 56.599 & & $1.011 \pm 0.002$ & 1.011 & & 50.273 & \\
\hline 25 & $1.121 \pm 0.001$ & 1.118 & 59.028 & & $1.073 \pm 0.002$ & 1.073 & & 53.356 & \\
\hline 10 & $1.187 \pm 0.001$ & 1.185 & 62.566 & & $1.195 \pm 0.002$ & 1.195 & & 59.423 & \\
\hline 5 & $1.215 \pm 0.002$ & 1.213 & 64.044 & & $1.221 \pm 0.002$ & 1.221 & & 60.716 & \\
\hline Untreated & $1.898 \pm 0.0005$ & 1.894 & 100 & & $2.013 \pm 0.002$ & 2.011 & & 100 & \\
\hline Blank & $0.004 \pm 0.0005$ & 0 & & & $0.002 \pm 0.0005$ & 0 & & & \\
\hline
\end{tabular}

\section{DISCUSSION}

Presence of Bacillus in marine habitat with potent antibiotic properties is gaining interest in recent years. Ramasubburayan et al.,( 2014) reported that B. pumilus, $B$. licheniformis, B. subtilis, B. mojavens and B. firmus are some of marine bacterial strains with antibiotic potential. B. flexus APGI, an active epibiotic bacterium of marine origin was extensively studied for maximizing the potential antibiotic property (Ramasubburayan et al., 2014). Present study was aimed to characterize a marine bacillus AVSC4 for its antibiotic potential. AVSC4 was identified as B.flexus AVSC4 with accession no MG878436.

Acclimatization of AVSC4 to neutral $\mathrm{pH}(\mathrm{pH} 7)$ from native alkaline habitat (Fig $2 \mathrm{c})$, thermal and osmotic stability by showing growth maxima at $40^{\circ} \mathrm{C}(\mathrm{Fig} 2 \mathrm{~b})$ and $4 \% \mathrm{NaCl}$ ( $\mathrm{Fig} \mathrm{3a}$ ) is a positive indication to the isolate for exploration of novel bioactive secondary metabolites . Earlier reports also revealed that $B$. flexus APGI required $40^{\circ} \mathrm{C}$ for enhancing growth and secondary metabolite biosynthesis (Ramasubburayan et al., 2014). B. subtilis has shown higher antimicrobia activity in the range of pH 7.0 and pH 8.0 (Muaaz et al., 2007) and other marine Bacillus sp showed potential production of antimicrobial metabolite at $\mathrm{pH} 8.0$ (Awais et al, 2008). Our results also revealed that the isolate AVSC4 showed potential antibacterial activity after $96 \mathrm{hrs}$ and $120 \mathrm{hrs}$ of incubation period at $40^{\circ} \mathrm{C}$, pH 7 and 8 , salinity $0.4 \%$ and $0.5 \%$ in correlation with growth (Table 1 ). However $40^{\circ} \mathrm{C}, \mathrm{pH} 7$ and $0.4 \% \mathrm{NaCl}$ have been selected in formulation of media.

Bacillus flexus APGI showed a consistent increase in antibacterial activity in the broth amended with galactose, fructose whereas mannitol recorded the higher degree of antibacterial activity (Ramasubburayan et al., 2014). Bacillus subtilis also effectively utilize mannitol as the best carbon source for promising antibacterial activity (Todorova and Kozhuharova, 2010). In contrast, our Bacillus flexus AVSC4 represented higher growth and potential antibacterial activity in the broth amended with glucose, sucrose and dextrose under optimized conditions of $40^{\circ} \mathrm{C}, \mathrm{pH} 7$ and $0.4 \% \mathrm{NaCl}$. As carbon sources play a major role in production medium which acts as source of energy and production of bioactive metabolites glucose a simple monosaccharide has been chosen as specific carbon source.

B. flexus AVSC4 has shown maximum growth in broth supplemented with peptone (Fig 3c) and maximum antibacterial activity in Beef extract (Table 1). Growth and antibacterial activity of B. flexus AVSC4 was reported maximum in methionine (Fig 3d). Earlier reports suggested meat extract and yeast extract were the best nitrogen sources for Bacillus sp. towards achieving maximum antibacterial activity (Nishanth Kumar et al., 2012). In order to induce the synthesis and production of precursors, $0.5 \%$ beef extract and $0.5 \%$ methionine were selected as inducers in our formuated medium. Though the isolate AVSC4 showed maximum growth and antibacterial activity after 96hrs and $120 \mathrm{hrs}$ of incubation periods, in order to shorten the length of bioprocessing and to avoid allosteric inhibition $96 \mathrm{hrs}$ of incubation has been standardized.

GC-MS analysis revealed the chemical composition of this extract which included heptadecanoic acid, was found to have the highest area. Earlier research reports show that fatty acids produced from bacteria exhibited antibacterial activities (Choi and Jiang, 2014) and as the biological labelling (Zhang et al., 2009). 9-12 Octadecenoic acid and Octadecanoic acid methyl ester were ninth and eleventh compounds which function as the antiacne, antieczemic, antihistaminic, anti-inflammatory, cancer preventive, hepatoprotective, hypocholesterolemic, insectifuge, nematicide, 5-alpha- eductase inhibitor antiandrogenic, antiarthritic, anti-coronary and insectifuge (Kalaivani et al. 2012)

In earlierbstudies Bacillus flexus $47 \mathrm{MM}$ isolated from Pensacola Bay has shown no significant antibacterial activity against $B$. subtilis, $P$. aeruginosa and $S$ aureus but, have shown anticancer activity against Pancreatic cancer cell line (PANC-1) and the multidrug- resistant ovarian cancer cell line NCI/ADR (Christensen and Martin, 2017). Significant antibacterial activity of ethyl acetate extract of bacillus flexus AVSC4 grown in formulated media against five test organisms Escherichia coli, Klebsiella pneumonia, Proteus vulgaris, Salmonella typhi, Serretia marcescens and Staphylococcus aureus (Fig 4) indicate that AVSC4 synthesized potential bioactive secondary metabolites under optimized culture conditions.

Bacillus thuriengiensis S13 and Bacillus flexus S15 exhibited a significant inhibition activity on A-549 lung cancer cell lines with IC 50 value of 120.39 $\mu \mathrm{g} / \mathrm{ml}$ and $133.27 \mu \mathrm{g} / \mathrm{ml}$. Marine Bacillus sp isolated from the Egyptian saline habitat produced bioactive compounds which have cytotoxic activity on hepatocellular carcinoma with IC50 (218 $\mu \mathrm{g} \mathrm{ml-1)}$ (Salma M Abdelnasser et al 2017). Ethyl acetate extract of B.flexus reported here could able to inhibit growth (Human colorectal adenocarcinoma cell line HT-29) at IC 50 value of $93.4 \mu \mathrm{g} / \mathrm{ml}$ and (Lung cancer cell line A-549) at IC 50 value of $50.04 \mu \mathrm{g} / \mathrm{ml}$ (Table 3).

\section{CONCLUSION}

Bacillus flexus AVSC4 is a marine bacteria with potent antibacterial activity Acclimatization to mesophilic condition, thermal and osmotic stability of the isolate are positive characteristics for the exploration of novel bioactive secondary metabolites of pharmaceutical significance. Presence of saturated fatty acids, antibacterial and anticancer activities of the crude extract of the isolate grown in formulated culture broth reveal that glucose, beef extract and methionine are potential inducers and play a pivotal role for the synthesis of novel bioactive secondary metabolites. Future studies on purification of active principles and mechanism of action would be required to elucidate potential usefulness of Bacillus flexus AVSC4.

Conflict of interest statement: No conflict of interest.

Acknowledgements: CSS gratefully acknowledges the funding support provided by the Department of Science and Technology, Ministry of Science and Technology, Government of India, New Delhi, under Inspire Fellowship- JRF (No. DST/INSPIRE Fellowship/2015/IF150034). Authors are grateful to Dr. Supriya for preparing Figure 1 and the anonymous reviewers for their valuable comments and also the authorities of Acharya Nagarjuna University for providing necessary facilities.

\section{REFERENCES}

Abdelnasser, S.M., Yahya, S.M., Mohamed, W.F., Asker, M.M., Abu Shady, H.M., Mahmoud, M.G., Gadallah M.A. (2017). Antitumor Exopolysaccharides Derived from Novel Marine Bacillus: Isolation, Characterization Aspect and Biological Activity. Asian Pac J Cancer Prev 18, 1847-1854. http://dx.doi.org/10.22034/APJCP.2017.18.7.1847

Awais, M., Pervez, A., Qayyum, S., Saleem, M. (2008). Effects of glucose, incubation period and $\mathrm{pH}$ on the production of peptide antibiotics by Bacillus pumilus. Afri J Microbiol Res 2, 114-119.

Balouiri, M., Sadiki, M., Ibnsouda, S. (2016). Methods for in vitro evaluating antimicrobial activity: A review J Pharm Anal 6, 71-79. http://dx.doi.org/10.1016/j.jpha.2015.11.005

Basa'ar, O., Fatema, S., Alrabie, A., Mohsin, M., Farooqui, M. (2017) Supercritical carbon dioxide extraction of Triognella foenum graecum Linn. seeds: Determination of bioactive compounds and pharmacological analysis. $\begin{array}{lllll}\text { Asian Pac J Trop } & \text { Biomed }\end{array}$ https://doi.org/10.1016/j.apjtb.2017.10.010

Bhatnagar, I., Kim, S.K. (2010). Immense Essence of Excellence: Marine Microbial Bioactive Compounds Mar Drugs. 8, 2673-

2701. http://dx.doi.org/10.3390/md8102673

Burgess, J.G., Miyashila, H., Sudo, H., Matsunaga, T. (1991). Antibiotic production by marine photosynthetic bacterium Chromatium purpuratum NKPB031704: Localization of activity in the chromatophres. FEMS Microbiol Lett 84, 301-306. https://doi.org/10.1111/j.1574-6968.1991.tb04614.x

Chalasani, A.G., Dhanarajan, G., Nema, S., Sen, R.K., Roy, U. (2015). An Antimicrobial Metabolite from Bacillus sp. Significant Activity Against Pathogenic Bacteria Including Multidrug-Resistant Clinical Strains. Front Microbiol. http://dx.doi: 10.3389 / fmicb. 2015. 01335

Chandini, S.S., Sairam, M., Amrutha, V.A. (2017). Screening for Antibacterial activity of Bacteria isolated from Marine sediment. Int J Curr Microbiol App Sci $5,37-44$.

Choi, W.H., Jiang, M.H. (2014). Evaluation of antibacterial activity of hexanedioic acid isolated from Hermetia illucens larvae. J App Biomed 12, 179 189. https://doi.org/10.1016/j.jab.2014.01.003

Christensen, A., Martin, G.D.A. (2017). Identification and bioactive potential of marine microorganisms from selected Florida coastal areas. MicrobiologyOpen. 6: e448. https://doi.org/10.1002/mbo3.448 
Dellar, J.E., Cole, M.D., Waterman, P.G. (1996). Unusual antimicrobial compounds from Aeollanthus buchnerianus. Experientia 52, 175-179.

Freese, E., Shew, C.W., Galliers, E. (1973). Function of lipophilic acids as antimicrobial food additives. Nature 241, 321-325.

Grossman, A.D. (1995). Genetic networks controlling the initiation of sporulation and the development of genetic competence in Bacillus subtilis. Annu Rev Genet 29,

http://dx.doi.org/10.1146/annurev.ge.29.120195.002401

Hyronimus, B., Le Marrec, C., Urdaci, M.C. (1998). Coagulin, a bacteriocin-like inhibitory substance produced by Bacillus coagulans $\mathrm{I}_{4}$. J Appl Microbiol. 85, 42-50. https://doi.org/10.1046/j.1365-2672.1998.00466.x

Jansen, E.F., Hirschmann, D.J. (1944). Subtilin, an antibacterial substance of Bacillus subtilis: culturing condition and properties. Arch Biochem 4, 297-309.

Jensen, P.R., Fenical, W. (1994). Strategies for the discovery of secondary metabolites from marine bacteria: ecological perspectives. Annu Rev Microbio 48, 559-584. http://dx.doi.org/10.1146/annurev.mi.48.100194.003015 Kalaivani, C.S., Sathish, S.S., Janakiraman, N., Johnson, M. (2012). GC-MS studies on Andrographis paniculata (Burm.f.) Wall ex. Ness-A Medicinally Important Plant. Int J Med Arom Plants 2, 69-74.

Kaneda, T. (1963). Biosynthesis of branched chain fatty acids. I. Isolation and identification of fatty acids from Bacillus subtilis (ATCC 7059). J Biol Chem $238,1222-1228$.

Lopez, A., Gerwick, W.H. (1988). Ptilodene, a novel icosanoid inhibitor of 5 lipoxygenase and $\mathrm{Na}+\mathrm{K}+$ ATPase from the red marine alga Ptilota filicina. $\mathrm{J}$. Agardh. Tet. Lett. 29, 1505-1506. http://dx.doi.org/10.1016/s00404039(00)80336-6

Ma, Z., Wang, N., Hu, J., Wang, S. (2012). Isolation and characterization of a new iturinic lipopeptide, mojavensin A produced by a marine-derived bacterium Bacillus mojavensis. J Antibio 65, 317-322. http://dx.doi.org/10.1038/ja.2012.19 Mayer, A.M., Rodríguez, A.D., Berlinck, R.G., Fusetani, N. (2011). Marine pharmacology in 2007-8: Marine compounds with antibacterial, anticoagulant, antifungal, anti-inflammatory, antimalarial, antiprotozoal, antituberculosis, an antiviral activities; affecting the immune and nervous system, and other miscellaneous mechanisms of action. Comp. Biochem Physiol C Toxicol Pharmacol 153, 191-222. https://doi.org/10.1016/j.cbpc.2010.08.008

Muaaz, M.A., Sheikh, M.A., Ahmad, Z., Hasnain, S. (2007). Production of surfactin from Bacillus subtilis MZ-7 grown on pharmamedia commercial medium. Microb Cell Fact 10, 6-17. http://dx.doi.org/10.1186/1475-2859-6-17

Nagar, S., Mittal, A., Kumar, D., Gupta, V.K. (2012). Production of alkalitolerant cellulase free xylanasein high levels by Bacillus pumilus SV-205. Int J Biol Macromol 50, 414-420. http://dx.doi.org/10.1016/j.ijbiomac.2011.12.026 Nishanth Kumar, S., Siji, J.V., Ramya, R., Nambisan, B., Mohandas, C. (2012). Improvement of antimicrobial activity of compounds produced by Bacillus sp associated with a Rhabditid sp. (Entomopathogenic Nematode) by changing carbon and nitrogen sources in fermentation media. J Microbiol Biotechnol Food Sci 1, 1424-1438.

Pfefferle, C., Kempter, C., Metzger, J.W., Fiedler, H.-P. (1996). E-4-oxonon-2enoic acid, an antibiotically active fatty acid produced by

Streptomyces olivaceus Tu 4018. J. Antibiot. 49, 826828.http://dx.doi.org/10.7164/antibiotics.49.826

Pomponi, S.A. (1999) The bioprocessin - technological potential of Sea. J Biotechnol 70, 513. https://doi.org/10.1016/S0168-1656(99)00053-X

Proksh, P., Edrada, R.A., Ebel, R. (2002). Drugs from the sea- Current status and microbiological implications. Appl Microbiol Biotechnol 59, 125-134. http://dx.doi.org/10.1007/s00253-002-1006-8

Ramasubburayan, R., Susan, T., Pradeep Kumar, V., Immanuel, G., Palavesam, A. (2014). Isolation, screening and optimization of culture conditions for enhanced antibacterial activity by a marine epibiotic bacterium Bacillus flexus APGI against fouling bacterial strains. J Pur Appl Microbiol 8, 2909-2920.

Ramachandran, R.D., Chalasani, A.G., Lal, R.A., Roy, U. (2014). A BroadSpectrum Antimicrobial Activity of Bacillus subtilis RLID 12.1. Sci World J http://dx.doi.org/10.1155/2014/968487

Ravikumar, S., Jacob Inbaneson, S., Sengottuvel, R., Ramu, A. (2010). Assessment of endophytic bacterial diversity among mangrove plants and their antibacterial activity against bacterial pathogens. Ann Biol Res 1, 240-247.

Stein, T. (2005). Bacillus subtilis antibiotics: structures, syntheses and specific functions. Mol Microbiol 56, 845-857. http://dx.doi.org/10.1111/j.13652958.2005.04587.x

Tamura, K., Peterson, D., Peterson, N., Stecher, G., Nei, M., Kumar, S. (2011). Molecular evolutionary genetics analysis using maximum likelihood, evolutionary distance, and maximum parsimony methods. Mol Biol Evol 28, 2731-2739. http://dx.doi.org/10.1093/molbev/msr121

Todorova, S., Kozhuharova, L. (2010). Characteristics and antimicrobial activity of Bacillus subtilis strains isolated from soil. World J Microbiol Biotechnol 26 , 1207-1216. http://dx.doi.org/10.1007/s11274-009-0290-1

Venkanna, A., Siva, B., Poornima, B., Vadaparthi, PR., Prasad, K.R., Reddy, K.A., Reddy, G.B., Babu, K.S. (2014). Phytochemical investigation of sesquiterpenes from the fruits of Schisandra chinensis and their cytotoxic activity. Fitoterapia 95, 102-108. http://dx.doi.org/10.1016/j.fitote.2014.03.003
Villa, F.A., Gerwick, L. (2010). Marine natural product drug discovery: Leads for treatment of inflammation, cancer, infections, and neurological disorders. $\begin{array}{llll}\text { Immunopharm Immunotoxicol } \quad 32, & 228-237 .\end{array}$ http://dx.doi.org/10.3109/08923970903296136

VonTersch, M.A., Carlton, B.C. (1983). Bacteriocin from Bacillus megaterium ATCC 19213: comparative studies with megacin A-216. J of Bacteriol 155, 866871.

Wenzel, S.C., Müller, R. (2005). Recent developments towards the heterologous expression of complex bacterial natural product biosynthetic pathways. Curr Opin Biotechnol 16, 594-606. http://dx.doi.org/10.1016/j.copbio.2005.10.001

Wulff, E.G., Mguni, C.M., Mansfeld-Giese, K., Fels, J., Lu“beck, M., Hockenhull, J. (2002). Biochemical and molecular characterization of Bacillus amyloliquefaciens, $B$. subtilis and $B$. pumilus isolates with distinct antagonistic potential against Xanthomonas campestris pv. campestris. Plant Patholo 51, 574584. https://doi.org/10.1046/j.1365-3059.2002.00753.x

Zhang, Q.B., Song, K., Zhao, J.W., Kong , X.G., Sun, Y.J., Liu, X.M., Zhang, Y.L., Zeng, Q.H., Zhang, H.J . (2009). Hexanedioic acid mediated surfaceligand-exchange process for transferring NaYF4: $\mathrm{Yb} / \mathrm{Er}$ (or $\mathrm{Yb} / \mathrm{Tm}$ ) upconverting nanoparticles from hydrophobic to hydrophilic. Colloid Interface Sci 336, 171-175. http://dx.doi.org/10.1016/j.jcis.2009.04.024

Zheng, L., Yi, Y., Liu, J., Lin, X., Yang, K., Lv, M., Zhou, X., Hao, J., Liu, J., Zheng, Y., Sun, M . (2014). Isolation and characterization of marine Brevibacillus sp. S-1 collected from South China Sea and a novel antitumor peptide produced by the strain. PLoS One. 9 ,11, e111270. https://doi.org/10.1371/journal.pone.0111270 